\title{
The ultrastructural damage caused by Eugenia zeyheri and Syzygium legatii acetone leaf extracts on pathogenic Escherichia coli
}

\author{
Ibukun M. Famuyide ${ }^{1}$, Folorunso O. Fasina ${ }^{2,3}$, Jacobus N. Eloff ${ }^{1 *}$ (i) and Lyndy J. McGaw ${ }^{1}$
}

\begin{abstract}
Background: Antibiotics are commonly added to livestock feeds in sub-therapeutic doses as growth promoters and for prophylaxis against pathogenic microbes, especially those implicated in diarrhoea. While this practice has improved livestock production, it is a major cause of antimicrobial resistance in microbes affecting livestock and humans. This has led to the banning of prophylactic antibiotic use in animals in many countries. To compensate for this, alternatives have been sought from natural sources such as plants. While many studies have reported the antimicrobial activity of medicinal plants with potential for use as phytogenic/botanical feed additives, little information exists on their mode of action. This study is based on our earlier work and describes ultrastructural damage induced by acetone crude leaf extracts of Syzygium legatii and Eugenia zeyheri (Myrtaceae) active against diarrhoeagenic E. coli of swine origin using scanning electron microscopy (SEM), transmission electron microscopy (TEM), and fluorescent microscopy (FM). Gas chromatography/mass spectrometry (GC-MS) was used to investigate the chemical composition of plant extracts.
\end{abstract}

Results: The extracts damaged the internal and external anatomy of the cytoplasmic membrane and inner structure at a concentration of $0.04 \mathrm{mg} / \mathrm{mL}$. Extracts also led to an increased influx of propidium iodide into treated bacterial cells suggesting compromised cellular integrity and cellular damage. Non-polar compounds such as aamyrin, friedelan-3-one, lupeol, and $\beta$-sitosterol were abundant in the extracts.

Conclusions: The extracts of $S$. legatii and E. zeyheri caused ultrastructural damage to E. coli cells characterized by altered external and internal morphology. These observations may assist in elucidating the mode of action of the extracts.

Keywords: Scanning Electron microscopy, Transmission Electron microscopy, Escherichia coli, Fluorescence microscopy, Myrtaceae, Eugenia, Syzygium

\footnotetext{
* Correspondence: kobus.eloff@up.ac.za

'Department of Paraclinical Sciences, Phytomedicine Programme, Faculty of

Veterinary Science, University of Pretoria, Private Bag X04, Onderstepoort

0110, South Africa

Full list of author information is available at the end of the article
}

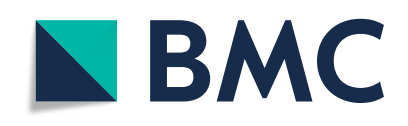

(c) The Author(s). 2020 Open Access This article is licensed under a Creative Commons Attribution 4.0 International License, which permits use, sharing, adaptation, distribution and reproduction in any medium or format, as long as you give appropriate credit to the original author(s) and the source, provide a link to the Creative Commons licence, and indicate if changes were made. The images or other third party material in this article are included in the article's Creative Commons licence, unless indicated otherwise in a credit line to the material. If material is not included in the article's Creative Commons licence and your intended use is not permitted by statutory regulation or exceeds the permitted use, you will need to obtain permission directly from the copyright holder. To view a copy of this licence, visit http://creativecommons.org/licenses/by/4.0/. The Creative Commons Public Domain Dedication waiver (http://creativecommons.org/publicdomain/zero/1.0/) applies to the data made available in this article, unless otherwise stated in a credit line to the data. 


\section{Background}

Antimicrobial resistance remains a major threat to human health globally. The use of antibiotics as growth promoters in livestock feeds is a major risk for development of antibiotic resistance in humans due to the presence of residual antibiotics in edible animal products and contamination of the environment with animal faecal matter [1, 2]. Due to the strong association between antibiotic resistance and the use of antimicrobials in livestock, especially as feed additives, some countries particularly in the European Union have banned use of antibiotics as growth promoters [3]. This has motivated the search for suitable alternatives including the use of standardized plant extracts or isolated compounds. Active and safe compounds isolated from plants can additionally serve as drug leads for therapeutic purposes [4].

Molecular biology techniques and microscopy are used to study the mechanism of action of antimicrobial compounds [5]. Electron microscopy is used in biomedical research to study the ultrastructural morphology of bacterial cells [6, 7]. Scanning and transmission electron microscopy aid the visualization of images at high resolution, providing detailed information on normal or abnormal external and internal cellular morphology such as the cell membrane, cytoplasm, nucleus, organelles and cytoskeletal structures [8,9]. These methods have greater advantages over conventional light microscopy because they are able to give three-dimensional images and higher image resolutions compared to light microscopy [10].

Although many studies have reported antibacterial activity of several plant extracts, fractions, and isolated compounds against a wide range of microbes however, information describing their ultrastructural effects are scanty.

Many Syzygium and Eugenia species have antimicrobial activity [11, 12]. The fruits and leaves of Eugenia zeyheri and $S$. legatii are consumed by humans and animals as food $[13,14]$. In a recent study, acetone leaf crude extracts of Eugenia zeyheri and Syzygium legatii had excellent antimicrobial activity with MICs varying from 0.04 to $0.23 \mathrm{mg} / \mathrm{ml}$ on clinical and reference strains of $E$. coli. It also reduced the attachment of $E$. coli to intestinal cells in a Caco- 2 cell adhesion assay [15].

This study described the morphological and ultrastructural alterations caused by crude acetone extracts of $S$. legatii and E. zeyheri on a diarrhoeagenic E. coli strain of swine origin, using scanning and transmission electron microscopy. The effect on membrane permeability of the bacterial cells upon treatment with the extracts was also investigated with propidium iodide which is an intact membrane-impermeable fluorescent dye [16]. Gas chromatography coupled with mass spectrometry (GC-MS) was used to investigate compounds present in the plant extracts.

\section{Results}

\section{Electron microscopy}

There were significant external ultrastructural changes in the scanning electron microscopic investigation of treated cells compared to the control cells as early as the third hour of treatment of bacteria with both plant extracts (Fig. 1d, e and 2a-f). Many of the cell
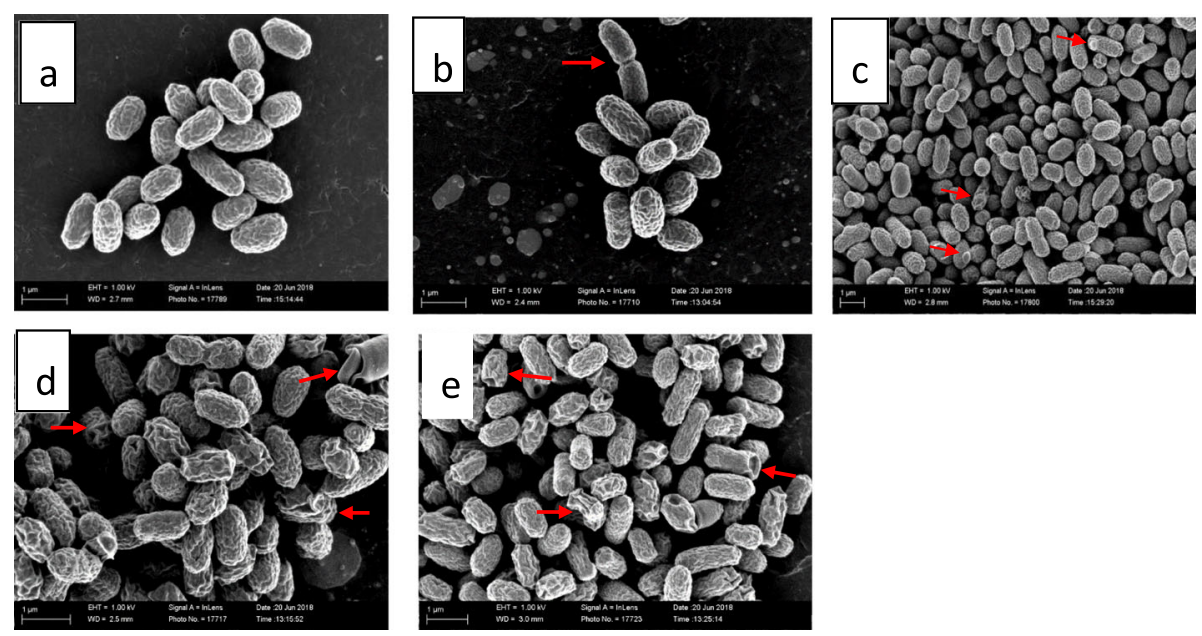

Fig. 1 Scanning electron microscopic morphology of: a = untreated E. coli cells (negative control) after $24 \mathrm{~h}$ (cells are clustered and have normal short rod shape and size.), $\mathbf{b}=$ solvent control after $24 \mathrm{~h}$ (cells are clustered and have normal short rod shape and size), $\mathbf{c}=E$. coli cells after $24 \mathrm{~h}$ exposure to $1 \mu \mathrm{g} / \mathrm{mL}$ gentamicin (many of the cells are normal with a few cells having rough or wrinkled surfaces and protrusions), $\mathbf{d}=$ E. coli cells after $3 \mathrm{~h}$ exposure to $0.04 \mathrm{mg} / \mathrm{mL}$ extract of Syzygium legatii (cells have rough or wrinkled surfaces, altered shape, cavitations and cracks), e = E. coli cells after 3-h exposure to extract of Eugenia zeyheri (cells are wrinkled, shrunken and rough with cavitations) 

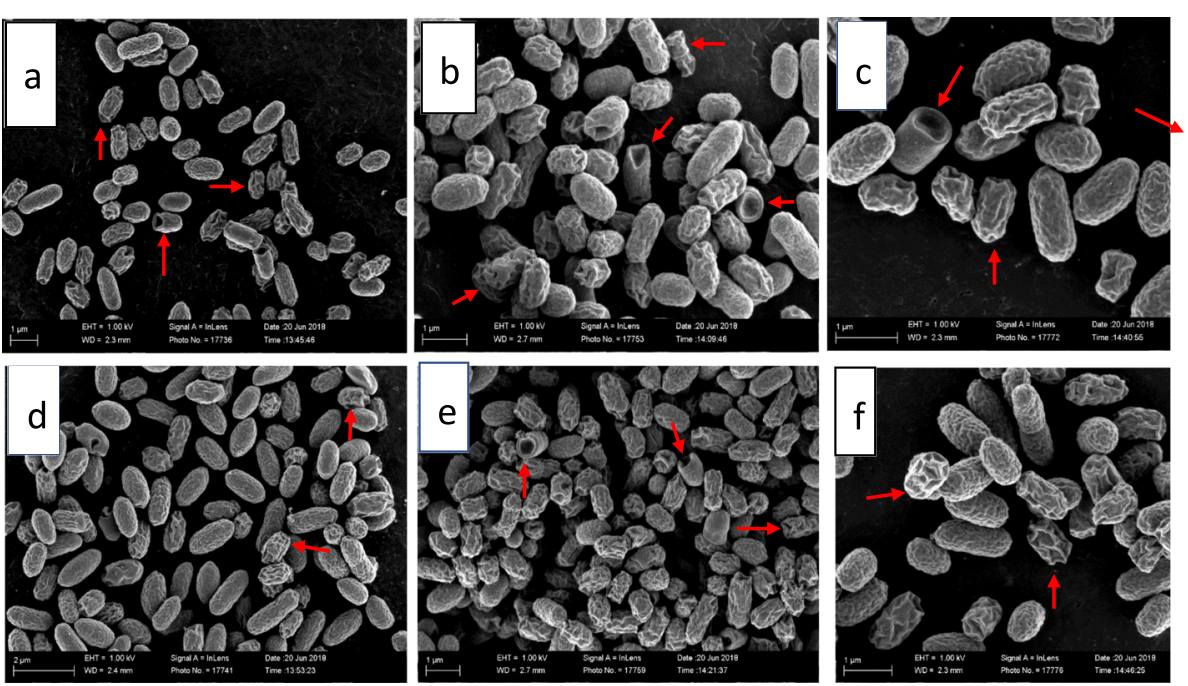

Fig. 2 Scanning electron microscopic morphology of E. coli cells: a = after $6 \mathrm{~h}$ exposure to $0.04 \mathrm{mg} / \mathrm{mL}$ extract of Syzygium legatii (cells have rough or wrinkled surfaces, altered shape, and telescoping or invagination of some cells), $\mathbf{b}=$ after $12 \mathrm{~h}$ exposure to $0.04 \mathrm{mg} / \mathrm{mL}$ extract of Syzygium legatii (cells have rough surfaces, altered shape, and telescoping or invagination of some cells, protrusions on the surface), $\mathbf{c}=$ after $24 \mathrm{~h}$ exposure to $0.04 \mathrm{mg} / \mathrm{mL}$ extract of Syzygium legatii (cells are wrinkled, shrunken and rough with surface protrusions), $\mathbf{d}=$ after 6 -h exposure to $0.04 \mathrm{mg} / \mathrm{mL}$ extract of Eugenia zeyheri (cells appear rough, twisted and wrinkled), $\mathbf{e}=$ after 12-h exposure to $0.04 \mathrm{mg} / \mathrm{mL}$ extract of Eugenia zeyheri (cells are wrinkled, shrunken, rough with cavitation, projections on the cell surface), $\mathbf{f}=$ after 24-h exposure to $0.04 \mathrm{mg} / \mathrm{mL}$ extract of Eugenia zeyheri (cells are wrinkled, shrunken, and rough

populations in both extract-treated bacteria appeared rough, twisted, wrinkled and misshapen. Some cells were telescoping or had invagination, while others had protrusions on their surfaces. These effects were observed after 6, 12 and $24 \mathrm{~h}$ of exposure of the bacteria to both plant extracts.

Observations from transmission electron microscopy (Fig. 3a-e and 4a-f) were also similar.
Alterations in the cells were observed as early as the $3 \mathrm{rd} \mathrm{h}$ of extract treatment (Fig. $3 \mathrm{~d}$ and $\mathrm{d}$ ), progressing till the 24th $\mathrm{h}$ of treatment. Some cells had chromatin condensation which was packed into apoptotic-like bodies (e.g. Figure 3d, e; Fig. 4e, f) while the membrane of some cells was detached from the cell wall with electron sparse cytoplasm (e.g. Figure 4c, and d).
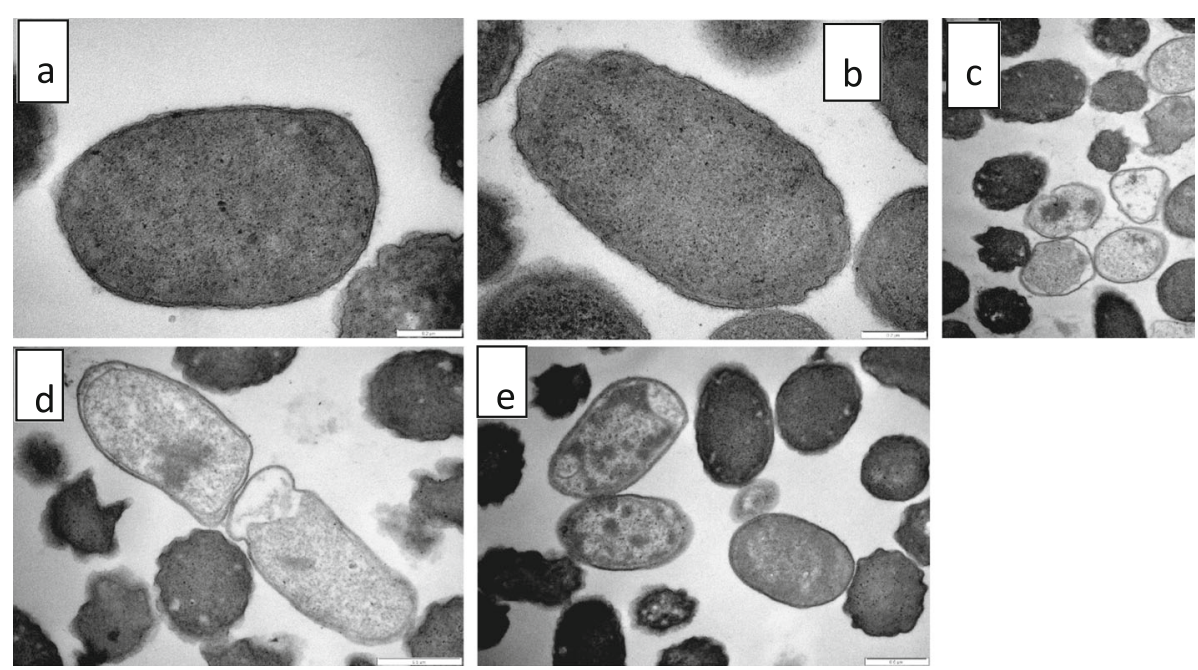

Fig. 3 Transmission electron microscopic morphology of $E$. coli cells: $\mathbf{a}=$ untreated control after $24 \mathrm{~h}$ (cell have uniform cytoplasmic density and intact cell membranes), $\mathbf{b}=$ acetone solvent control after $24 \mathrm{~h}$ (cells have uniform cytoplasmic density, intact cell membrane), $\mathbf{c}=$ gentamicintreated cells after $24 \mathrm{~h}$ (some cells are electron sparse, and detached from the cell wall), $\mathbf{d}$ = after 3-h exposure to $0.04 \mathrm{mg} / \mathrm{mL}$ extract of Syzygium legatii (cell membrane detaching from cell, translucent cytoplasm, shrunken, misshapen cells), e = after 3-h exposure to $0.04 \mathrm{mg} / \mathrm{mL}$ extract of Eugenia zeyheri (cell membrane detaching from cell, with islands of condensed chromatin) 

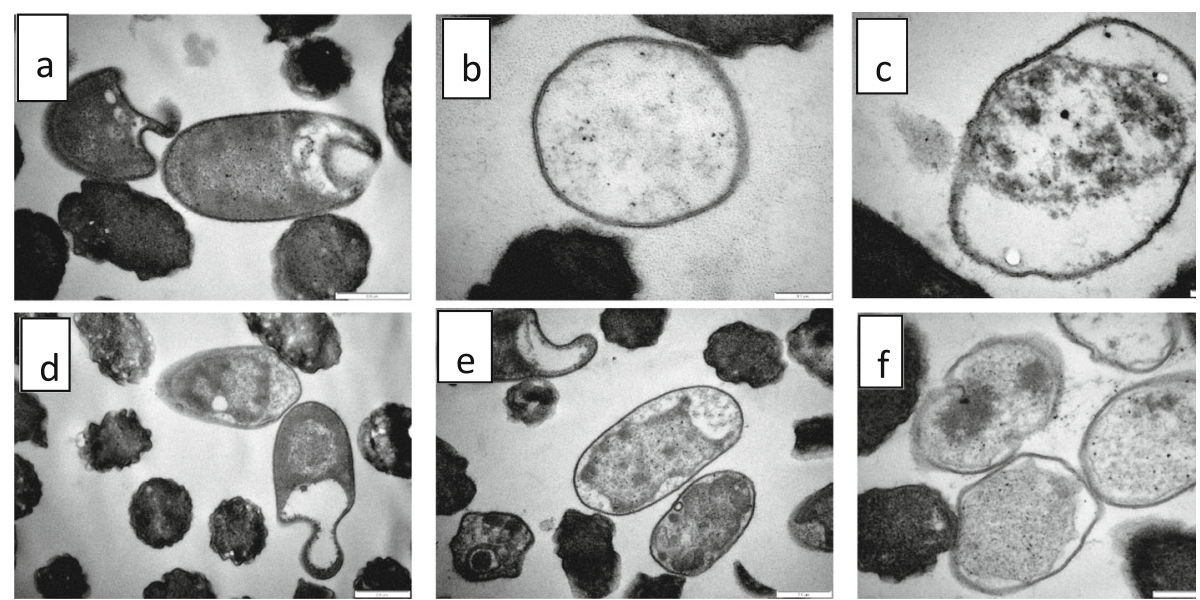

Fig. 4 Transmission electron microscopic morphology of E. coli cells: a = after 6-h exposure to $0.04 \mathrm{mg} / \mathrm{mL}$ extract of Syzygium legatii (cell membrane detaching from cell, misshapen cells), $\mathbf{b}=$ after 12 -h exposure to $0.04 \mathrm{mg} / \mathrm{mL}$ extract of Syzygium legatii (late stage cell death. Ghost cells with no cytoplasmic content. Cell walls appear intact), $\mathbf{c}=$ after $24-\mathrm{h}$ exposure to $0.04 \mathrm{mg} / \mathrm{mL}$ extract of Syzygium legatii (cell at late stage of death, condensed chromatin), $\mathbf{d}$ = after 6 -h exposure to $0.04 \mathrm{mg} / \mathrm{mL}$ extract of Eugenia zeyheri (cell membrane detaching from cell, misshapen cells with loss of structure), $\mathbf{e}=$ after 12 -h exposure to $0.04 \mathrm{mg} / \mathrm{mL}$ extract of Eugenia zeyheri (cell membrane detaching from cell, misshapen cells with loss of turgidity, condensation and aggregation of nuclear chromatin), $\mathbf{f}=$ after 24 -h exposure to $0.04 \mathrm{mg} / \mathrm{mL}$ extract of Eugenia zeyheri (cells show detachment of membrane from cell wall. Electron sparse cytoplasm, condensed chromatin)

\section{Fluorescent microscopy}

Fluorescent microscopic results revealed an increased entry of the fluorescent dye into extract-treated bacterial cells, seen by the amount of fluorescence in treated cells compared to the untreated control (Fig. 5d and e). A small amount of red fluorescence was observed in the untreated control (Fig. 5a) which showed that most of the bacterial cells were viable and the fluorescence observed may be due to small bacteria that died naturally, while more fluorescence was observed in heat-killed bacteria (Fig. 5b).

\section{Gas chromatography-mass spectroscopy analysis of plant extracts}

The gas chromatographic-mass spectrometric analysis of acetone leaf extracts of E. zeyheri (Table 1) and S. legatii (Table 2) revealed the presence of compounds such as terpenes, steroids, alkane hydrocarbons, epoxides, and saturated fatty acids. Lupeol and $\alpha$-Amyrin were most abundant in E. zeyheri while friedelan-3-one was most abundant in S. legatii.

$R T$ Retention time, $M W$ Molecular weight. $R T$ Retention time, $M W$ Molecular weight.
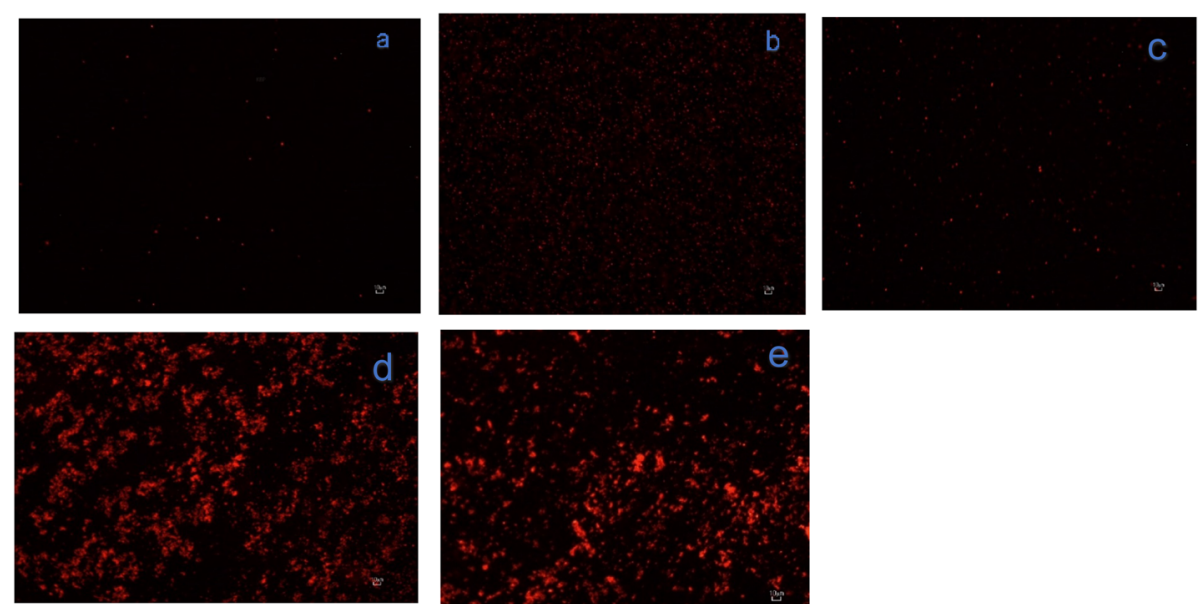

Fig. 5 Fluorescence microscopy images of $E$. coli stained with propidium iodide: a negative control (untreated), b negative control (heat -killed), $\mathbf{c}$ gentamicin $(1 \mathrm{\mu g} / \mathrm{mL})$ treated for $3 \mathrm{~h}$, d S. legatii $(0.04 \mathrm{mg} / \mathrm{mL})$ treated for $3 \mathrm{~h}$, e) E. zeyheri $(0.04 \mathrm{mg} / \mathrm{mL})$ treated for $3 \mathrm{~h}$. The red fluorescence indicates cells with damaged membrane 
Table 1 Major compounds detected in the acetone crude leaf extract of Eugenia zeyheri by GC-MS

\begin{tabular}{|c|c|c|c|c|c|c|}
\hline $\mathrm{S} / \mathrm{N}$ & Compound & $\mathrm{RT}(\mathrm{s})$ & Molecular formula & MW & $\%$ Peak Area & Similarity index (\%) \\
\hline 1 & a-Amyrin & 1684.7 & $\mathrm{C}_{30} \mathrm{H}_{50} \mathrm{O}$ & 426 & 23.272 & 88.9 \\
\hline 2 & Lupeol & 1687.1 & $\mathrm{C}_{30} \mathrm{H}_{50} \mathrm{O}$ & 426 & 24.165 & 89.4 \\
\hline 3 & $\gamma$-Sitosterol & 1658.2 & $\mathrm{C}_{29} \mathrm{H}_{50} \mathrm{O}$ & 414 & 0.22951 & 62.8 \\
\hline 4 & 2,6,10-Dodecatriene, 1-bromo-3,7,11-trimethyl- & 1654 & $\mathrm{C}_{15} \mathrm{H}_{25} \mathrm{Br}$ & 284 & 1.6429 & 79.9 \\
\hline 5 & Olean-12-en-3ß-ol (6Cl,8Cl) & 1663.1 & $\mathrm{C}_{30} \mathrm{H}_{50} \mathrm{O}$ & 426 & 4.9815 & 89.2 \\
\hline 6 & Decane & 133.3 & $\mathrm{C}_{10} \mathrm{H}_{22}$ & 142 & 0.3568 & 95.2 \\
\hline 7 & trisiloxane, 1,1,1,5,5,5-hexamethyl-3-[(trimethylsilyl)oxy]- & 134.6 & $\mathrm{C}_{9} \mathrm{H}_{28} \mathrm{O}_{3} \mathrm{Si}_{4}$ & 296 & 0.3568 & 75.2 \\
\hline 8 & Dodecane & 315.8 & $\mathrm{C}_{12} \mathrm{H}_{26}$ & 170 & 0.44363 & 94.4 \\
\hline 9 & Tetradecane & 505.4 & $\mathrm{C}_{14} \mathrm{H}_{30}$ & 198 & 0.45213 & 96.1 \\
\hline 10 & Diethyl phthalate & 632.2 & $\mathrm{C}_{12} \mathrm{H}_{14} \mathrm{O}_{4}$ & 222 & 0.042262 & 94.1 \\
\hline 11 & Hexadecane & 679.2 & $\mathrm{C}_{16} \mathrm{H}_{34}$ & 226 & 0.28988 & 94.6 \\
\hline 12 & n-Hexadecanoic acid & 959.8 & $\mathrm{C}_{16} \mathrm{H}_{32} \mathrm{O}_{2}$ & 256 & 0.47217 & 91.9 \\
\hline 13 & Heneicosane & 1112.5 & $\mathrm{C}_{21} \mathrm{H}_{44}$ & 296 & 0.45644 & 93.2 \\
\hline 14 & Squalene & 1450.9 & $\mathrm{C}_{30} \mathrm{H}_{50}$ & 410 & 0.21611 & 92.1 \\
\hline 15 & Dl-a-Tocopherol & 1592.5 & $\mathrm{C}_{29} \mathrm{H}_{50} \mathrm{O}_{2}$ & 430 & 0.68369 & 88.2 \\
\hline
\end{tabular}

\section{Discussion}

Microscopic techniques have long been used to assess changes in cells. The changes in the bacterial morphology were determined by scanning (SEM) and transmission electron microscopy (TEM) at different times of exposure while cellular integrity after a $3 \mathrm{~h}$ treatment with extracts was determined by fluorescence microscopy. SEM provides insight on the effects of antibacterial agents on external morphology and surface characteristics of bacterial cells, while TEM indicates the internal architecture of normal and abnormal cells. The two techniques combined can give a useful understanding of the antibacterial mechanism of action of novel antibacterial agents [8]. The negative control (acetone) had no effect on the ultrastructure, but the positive control (gentamicin) caused many of the bacterial cells to have roughened or wrinkled surfaces with some having protrusions.

The appearance of some cells with chromatin condensation packed into apoptotic-like bodies are hallmarks of cellular apoptosis [17]. It can be inferred that many of the treated bacterial cells by the plant extracts may be undergoing apoptosis. Therefore, the mode of action of the plant extracts may be by causing apoptosis directly or indirectly.

Table 2 Major compounds detected in the acetone crude leaf extract of Syzygium legatii by GC-MS

\begin{tabular}{|c|c|c|c|c|c|c|}
\hline $\mathrm{S} / \mathrm{N}$ & Compound & $\mathrm{RT}(\mathrm{s})$ & Molecular formula & MW & $\%$ Peak Area & Similarity index (\%) \\
\hline 1 & Friedelan-3-one & 1734.2 & $\mathrm{C}_{3} \mathrm{OH}_{50} \mathrm{O}$ & 426 & 4.6496 & 88.8 \\
\hline 2 & Oleanolic acid & 1842 & $\mathrm{C}_{3} \mathrm{OH}_{48} \mathrm{O}_{3}$ & 456 & 1.3333 & 80.4 \\
\hline 3 & Urs-12-en-28-ol & 1814.1 & $\mathrm{C}_{3} \mathrm{OH}_{50} \mathrm{O}$ & 426 & 1.17 & 84.5 \\
\hline 4 & a-Amyrin & 1680.5 & $\mathrm{C}_{3} \mathrm{OH}_{50} \mathrm{O}$ & 426 & 1.2047 & 88.8 \\
\hline 5 & Dl-a-Tocopherol & 1592.4 & $\mathrm{C}_{29} \mathrm{H}_{50} \mathrm{O}_{2}$ & 430 & 1.4543 & 89.5 \\
\hline 6 & 3,7,11,15-Tetramethyl-2-hexadecen-1-ol & 892.6 & $\mathrm{C}_{20} \mathrm{H}_{40} \mathrm{O}$ & 296 & 1.1379 & 89.3 \\
\hline 7 & Neophytadiene & 862.3 & $\mathrm{C}_{20} \mathrm{H}_{38}$ & 278 & 1.5963 & 89.7 \\
\hline 8 & 3-Eicosene, (E)- & 800.9 & $\mathrm{C}_{20} \mathrm{H}_{40}$ & 280 & 1.2195 & 81.1 \\
\hline 9 & Hexadecane & 679.5 & $\mathrm{C}_{16} \mathrm{H}_{34}$ & 226 & 1.6552 & 94.3 \\
\hline 10 & Caryophyllene oxide & 642.4 & $\mathrm{C}_{15} \mathrm{H}_{24} \mathrm{O}$ & 220 & 1.8127 & 89 \\
\hline 11 & 4H-Imidazol-4-one, 2-amino-1,5-dihydro- & 614.7 & $\mathrm{C}_{3} \mathrm{H}_{5} \mathrm{~N}_{3} \mathrm{O}$ & 99 & 1.3649 & 80.4 \\
\hline 12 & Tetradecane & 505.9 & $\mathrm{C}_{14} \mathrm{H}_{30}$ & 198 & 2.649 & 94.3 \\
\hline 13 & Dodecane & 316.6 & $\mathrm{C}_{12} \mathrm{H}_{26}$ & 170 & 2.5936 & 94.2 \\
\hline 14 & Ethanedicarboxamide, N-(3,5-dimethylphenyl)-N'-[2-(1-piperazinyl)ethyl]- & 317.9 & $\mathrm{C}_{16} \mathrm{H}_{24} \mathrm{~N}_{4} \mathrm{O}_{2}$ & 304 & 2.628 & 92.4 \\
\hline 15 & Decane & 135.6 & $\mathrm{C}_{10} \mathrm{H}_{22}$ & 142 & 1.8075 & 96 \\
\hline
\end{tabular}


The changes are similar to those observed in previous studies with silver ion [5], polymyxin-B and miconazole [18], as well as honey [19] on E. coli. In a related study, exposure of pathogenic $E$. coli to cranberry extracts caused morphological damage such as cellular deformation, breakage of cell wall and membrane, condensation of cellular material, and presence of large amounts of cytoplasmic material and membrane debris in the cell's surrounding environment [20]. These results, which are like our findings, showed that the plant extracts induced pathological damage to E. coli possibly through primary effects on metabolism that led to the alteration of cellular structures. In one study, treatment of Bacillus cereus and Campylobacter jejuni with the ethanolic extract of Annona squamosa caused alterations and distortions in bacterial cell shape, abnormal elongations, leakage of intracellular contents, and depletion of the cytoplasm [8]. In another study, treatment of E. coli with the ethanol extract of clove buds (Syzygium aromaticum) caused loss of regular cellular shapes and cell membrane disintegration from the cell wall [21]. Treatment of E. coli with cinnamaldehyde caused the separation of cytoplasmic membranes from the cell wall, cell wall and cell membrane lysis, cytoplasmic content leakage, cytoplasmic content polarization, and cell distortion [22]. These findings are similar to those of the present study. The outcome of this study may therefore provide further insights into innovative alternative methods of bacterial management through disruption of the pathogen integrity.

The integrity of the bacterial membrane following exposure to E. zeyheri and S. legatii was assessed using a fluorescent dye, propidium iodide. This dye is known to intercalate with bases of deoxyribonucleic acid (DNA) to fluoresce. Propidium iodide can enter only a compromised bacterial cell membrane to bind with DNA as an intact cell membrane will exclude it.

Increased fluorescence was detected in gentamicintreated cells, indicating that it also affected the cell membrane. The primary effect of gentamicin on bacteria is to bind on the $30 \mathrm{~S}$ subunit of bacterial ribosome, the structural damage observed is therefore a secondary effect. The high fluorescence observed from treatment of bacteria with the extract of E. zeyheri and S. legatii indicated damage to the integrity of the bacterial cell membrane. In a similar study, the aqueous extract of Cassia alata caused a high number of cell deaths in Streptococcus epidermidis and Pseudomonas aeruginosa based on fluorescence microscopy [23].

The fluorescence results support the observations in the electron microscopy study. Cell abnormalities observed in the electron microscopy results such as abnormal cellular integrity, and/or partial or complete loss of cytoplasmic contents may be responsible for the highly permeable state of the cells to PI. It appeared that the compounds present in the extracts were able to penetrate the peptidoglycan layer of the bacterial cell into the cell membrane to exert the antibacterial effects. Possible targets for the compounds may be present on this layer [24]. More studies are needed to confirm these observations. In a previous study, lupeol, isolated from Curtisia dentata leaves had antibacterial activity against $E$. coli (ATCC 25922) with an MIC of $250 \mu \mathrm{g} / \mathrm{mL}$ [25]. In another report, $\alpha$-amyrin had an MIC of $64 \mu \mathrm{g} / \mathrm{mL}$ against Staphylococcus aureus (ATCC 43300) [26]. It may be worthwhile to isolate and characterize the bioactive compounds from the plant extracts from this study and determine their antibacterial activity and safety which may serve as new antibacterial drugs.

\section{Conclusion}

The extracts of S. legatii and E. zeyheri caused morphological and ultrastructural damage to E. coli when exposed to inhibitory concentrations of the extracts. These effects were characterized by disruptions and disfigurations in the cell shape and surface cell wall formation. The extracts affected the membrane integrity of the bacterial cells shown by increased fluorescence. We conclude that the plant extracts have potential for therapeutic use. Further work may include exploring the molecular mechanisms and precise cellular target(s) responsible for the effects seen in this study.

\section{Methods}

Collection of plant material, drying and storage

After obtaining the necessary permit, leaves of two selected plants namely Eugenia zeyheri (Harv.) Harv. and Syzygium legatii Burtt Davy \& Greenway were harvested in April 2017, at the Lowveld National Botanical Garden in Nelspruit, Mpumalanga, South Africa. Herbarium specimens were prepared and deposited in the HGWJ Schweickerdt Herbarium of the University of Pretoria for authentication while herbarium specimen identity number (PRU) were obtained. These were 123,617 and 123,619 for E. zeyheri and S. legatii respectively. The leaves were placed in open mesh loosely woven bags and dried under room temperature with adequate ventilation. Using a Janke and Künkel Model A10 mill, the dried leaves were ground to a fine powder, weighed and stored in at room temperature in closed jam jars [27].

\section{Extraction}

Two grams of dried powdered plant material was extracted with $20 \mathrm{~mL}$ of acetone technical grade, Merck) in $50 \mathrm{~mL}$ centrifuge tubes. Acetone is widely considered a solvent of choice because it can extract compounds with a wide range of polarities, it is relatively easy to remove from extracts and it is non-toxic to bioassays systems 
[28]. The tube containing the mixture was vigorously shaken and sonicated for 20 min followed by centrifugation for $10 \mathrm{~min}$ at $4000 \mathrm{X} \mathrm{g}$. The supernatant was then filtered using a Whatman No. 1 filter paper into a preweighed glass container and then dried under a cold stream of air in a fume hood at room temperature to obtain a dried extract. The dried extracts for were dissolved in the required volume of acetone for the bioassays.

\section{Bacterial strain}

An enterotoxigenic E. coli (possessing the STA and F6 virulence genes) isolated from a diarrhoeic piglet was obtained from the Department of Veterinary Tropical Diseases, Faculty of Veterinary Sciences, University of Pretoria. The organism was maintained on Tryptic Soy Agar (TSA, Oxoid) at $4{ }^{\circ} \mathrm{C}$.

\section{Preparation of E. coli culture for electron microscopy}

Escherichia coli was grown in TSA for $18 \mathrm{~h}$ after which a single colony was inoculated into Tryptic Soy Broth aseptically and incubated at $37^{\circ} \mathrm{C}$ on a shaker for $18 \mathrm{~h}$. After this, an inoculum equivalent to a McFarland No 1 standard $\left(3.6 \times 10^{8} \mathrm{cfu} / \mathrm{mL}\right)$ was prepared from the $18 \mathrm{~h}$ culture. Prior to this, TSA was prepared, and $5 \mathrm{~mL}$ of the molten agar was gently poured into $35 \mathrm{~mm}$ diameter sterile tissue culture plates to form a smooth and evenly spread surface and allowed to solidify in a sterile environment. The 35 $\mathrm{mm}$ agar plates were inoculated with the appropriately adjusted $E$. coli suspension which were spread evenly on the agar surface with a sterile glass spreader. The plates were then incubated at $37^{\circ} \mathrm{C}$ for $12 \mathrm{~h}$ under aerobic conditions. The plates were divided into two groups. Plates in group one was flooded with $100 \mu \mathrm{l}$ of E. zeyheri extract while those in group two were flooded with the extract of $S$. legatii, both at $0.04 \mathrm{mg} / \mathrm{mL}$ in acetone. This concentration represented the minimum inhibitory concentration of the extracts on the test bacterium in our previous study. One plate was flooded with $100 \mu \mathrm{l}$ of $50 \%$ acetone to represent the solvent control. One plate also served as the untreated control, while another was treated with $100 \mu \mathrm{l}$ gentamicin $(1 \mu \mathrm{g} / \mathrm{mL})$ as positive control. The plates were then incubated under aerobic conditions at $37^{\circ} \mathrm{C}$. After $0,3,6,12$, and $24 \mathrm{~h}$, separate plates were removed from the incubator and flooded with $1 \mathrm{~mL}$ of $2.5 \%$ glutaraldehyde in 0.075 $\mathrm{M}$ phosphate buffer solution ( $\mathrm{pH}$ 7.4) to fix the samples for $60 \mathrm{~min}$. The bacterial biofilms were then collected from each plate using sterile loops and transferred into 2 $\mathrm{mL}$ microcentrifuge tubes containing $1.5 \mathrm{~mL}$ of $0.5 \%$ glutaraldehyde in order to fix the cells for $1 \mathrm{~h}$. Glutaraldehyde was removed with a pipette and the cells were washed thrice with $0.075 \mathrm{M}$ sodium buffer for $10 \mathrm{~min}$ each. The samples were then fixed with osmium tetroxide $\left(\mathrm{OsO}_{4}\right.$, Merck, Darmstadt, Germany) in a fume hood for $30 \mathrm{~min}$.
Osmium tetroxide was removed and the cells were rinsed three times with the sodium phosphate buffer. Dehydration was done with increasing ethanol concentrations of 50, 70, 90 and 100\% for 15 min each. The 100\% ethanol step was repeated three times before preparation for scanning and transmission electron microscopy.

\section{Scanning electron microscopy (SEM) sample processing}

Following the last 100\% ethanol dehydration from the step above, hexamethyldisilazane (HMDS) was added at $50 \%$ in ethanol for $30 \mathrm{~min}$. Hexamethyldisilazane/ethanol was replaced with two changes of pure HMDS for $1 \mathrm{~h}$ each. A small droplet $(0.05 \mathrm{~mL})$ containing sample was placed on highly polished carbon discs and left open in a fume hood to dry overnight. These carbon discs were stuck using double-sided carbon tape onto aluminium stubs. Samples were made conductive by exposure to ruthenium tetroxide $\left(\mathrm{RuO}_{4}\right)$ for $45 \mathrm{~min}$ [29]. Samples were then viewed with a Zeiss Ultra Plus Field Emission Gun Scanning Electron Microscope (FEGSEM) at the Electron Microscope Unit of the University of Pretoria.

\section{Transmission electron microscopy (TEM) sample processing}

After the third dehydration step in $100 \%$, ethanol was removed and replaced with propylene for $2 \mathrm{~h}$. The propylene oxide was replaced with an Epon type epoxy resin (TAAB 812) and infiltrated for $5 \mathrm{~h}$. Pellets were removed from the microcentrifuge tubes, placed in embedding moulds, and polymerised for $48 \mathrm{~h}$. After this, sections were made with a Reichert Ultracut E ultramicrotome using a diamond knife and picked up onto copper grids. The sections on the grid were stained with $2 \%$ uranyl acetate followed by 2 min staining in Reynold's lead citrate. Sections were viewed and photographed with a Philips EM 10 transmission electron microscope (Eindhoven, Netherlands) in the Electron Microscopy Unit, Department of Anatomy and Physiology, Faculty of Veterinary Sciences, University of Pretoria.

\section{Propidium iodide (PI) uptake assay: cell viability assessment}

This was done as previously reported [30] with slight modifications. Briefly, the E. coli cells were grown in TSB for $18 \mathrm{~h}$, washed twice with phosphate buffer saline (PBS) and then adjusted to $10^{6} \mathrm{CFU} / \mathrm{mL}$ with PBS. The cells were then incubated at $37^{\circ} \mathrm{C}$ with the extracts of $E$. zeyheri and S. legatii at the MIC concentrations (0.04 $\mathrm{mg} / \mathrm{mL}$ respectively) for $3 \mathrm{~h}$. Gentamicin $(1 \mu \mathrm{g} / \mathrm{mL})$ served as positive control, untreated cells served as untreated negative control while heat-killed $\left(70{ }^{\circ} \mathrm{C}\right.$ for 60 min) bacteria served as treated negative control. Following incubation, cells were washed twice with PBS and fixed with $3.7 \%$ paraformaldehyde in $0.1 \mathrm{M}$ cacodylate 
buffer for $20 \mathrm{~min}$ at room temperature. Cells were then washed twice with PBS and incubated with PI at $37^{\circ} \mathrm{C}$ for $30 \mathrm{~min}$ in the dark. Cells were spread on a glass slide, covered by a cover slip and observed using a Nikon Eclipse TS 100-U inverted fluorescence microscope (Nikon, Champigny sur Marne, France) fitted with a Nikon Intensilight C-HGFI lamp unit at excitation and emission wavelengths of 536 and $617 \mathrm{~nm}$ respectively. Images were captured at $20 \mathrm{x}$ magnification.

\section{Gas chromatography-mass spectrometry (GC-MS) of plant extracts}

Analysis of chemical constituents of plant extracts of $S$. legatii and E. zeyheri were carried out in a LECO Pegasus 4D GC-TOFMS (LECO Africa (Pty) Ltd., Kempton Park, South Africa) on an apolar Rxi-5SilMS $30 \mathrm{~m} \times 0.25 \mathrm{~mm}$ ID $\times 0.2 \mu \mathrm{m}$ film thickness (Restek, Bellefonte, PA, USA) gas chromatography capillary column. Compound spectra were detected by electron ionization system $(70 \mathrm{eV})$. Ultra-high purity grade carrier gas, Pure helium gas (Afrox, South Africa) was set at a constant flow rate of 1 $\mathrm{mL} / \mathrm{min}$. Oven temperature was held for $3 \mathrm{~min}$ with $5 \mathrm{~min}$ solvent delay programmed at $40^{\circ} \mathrm{C}$ and held isothermally at $300{ }^{\circ} \mathrm{C}$ for $5 \mathrm{~min}$. A $1 \mu \mathrm{L}$ of acetone solution of the sample was injected in a splitless mode (splitless time 30s) with the injector temperature at $250^{\circ} \mathrm{C}$. Ion source temperature was maintained at $280^{\circ} \mathrm{C}$. A scan interval of $0.5 \mathrm{~s}$ and fragments from 40 to $550 \mathrm{Da}$ was maintained. Relative quantity of the compounds in extracts was expressed as a percentage based on the peak area produced in the chromatogram. Tentative identification of the bioactive constituents was done by comparison of retention times with standard samples and by matching the spectral fragmentation patterns against commercial library mass spectra. Analysis was done at the Department of Chemistry, University of Pretoria, South Africa.

\section{Abbreviations}

STA: Heat-stable enterotoxin gene A; F6: Fimbrial adhesin subunit 6; PI: Propidium iodide; SEM: Scanning Electron Microscopy; TEM: Transmission Electron Microscopy

\section{Acknowledgements}

The curators of the Lowveld National Botanical Garden and the University of Pretoria Manie van der Schyff Botanical Garden allowed us to collect plant material. Ms. Magda Nel and Ms. Elsa Van Wyk of the HGWJ Schweickerdt Herbarium of the University of Pretoria assisted in preparing voucher specimens. Special thanks to Mr. C. Van Der Merwe for the preparation of slides and guiding the use of the electron microscope. Dr. L. du Plessis and Ms. A. Lensink of the Electron Microscopy Unit of the Department of Anatomy and Physiology, Faculty of Veterinary Science also provided valuable assistance.

\section{Authors' contributions}

IMF carried out the research and wrote the first draft of the manuscript. FOF revised the manuscript. LJM guided the research project and revised the manuscript. JNE helped with plant collection, guided the research, revised, and submitted the manuscript. All authors read and approved the final manuscript.

\section{Funding}

IMF acknowledges the financial support of the South African National Research Foundation/The World Academy of Science (Grant No. 99808) and the University of Pretoria. The National Research Foundation provided research funding to LJM (Grant No 105993). The funders were not involved in the design, collection, analyses, and interpretation of the data presented in this study. The University of Pretoria also provided postdoctoral funding to IMF.

\section{Availability of data and materials}

The datasets used and/or analysed during the current study are available from the corresponding author on reasonable request. The plant material collected from the botanical gardens is available from the corresponding author on reasonable request.

Ethics approval and consent to participate

Not applicable because experiments did not involve animals or humans. Sampling of plant material was from our own University Botanical Garden and from the Lowveld National Botanical Garden in accordance with an agreement between the Phytomedicine Programme and the National Biodiversity Institute.

\section{Consent for publication}

Not applicable.

\section{Competing interests}

The authors declare that they have no competing interests.

\section{Author details}

${ }^{1}$ Department of Paraclinical Sciences, Phytomedicine Programme, Faculty of Veterinary Science, University of Pretoria, Private Bag X04, Onderstepoort 0110, South Africa. ${ }^{2}$ Dept of Veterinary Tropical Diseases, Faculty of Veterinary Science, University of Pretoria, Private Bag X04, Onderstepoort 0110, South Africa. ${ }^{3}$ Present Address: Emergency Centre for Transboundary Animal Diseases-Food and Agriculture Organization of the United Nations (ECTA D-FAO), House H. Sida, Ali Hassan Mwinyi Road, Ada Estate, Dar es Salaam, Tanzania.

Received: 20 August 2019 Accepted: 27 August 2020

Published online: 04 September 2020

\section{References}

1. Aarestrup FM. The livestock reservoir for antimicrobial resistance: a personal view on changing patterns of risks, effects of interventions and the way forward. Phil Trans R Soc B. 2015;370(1670):20140085

2. Tang KL, Caffrey NP, Nóbrega DB, Cork SC, Ronksley PE, Barkema HW, Polachek AJ, Ganshorn H, Sharma N, Kellner JD, et al. Restricting the use of antibiotics in food-producing animals and its associations with antibiotic resistance in food-producing animals and human beings: a systematic review and meta-analysis. Lancet Planet Health. 2017;1(8):e316-27.

3. Casewell M, Friis C, Marco E, McMullin P, Phillips I. The European ban on growth-promoting antibiotics and emerging consequences for human and animal health. J Antimicrob Chemother. 2003;52(2):159-61.

4. Gadde U, Kim WH, Oh ST, Lillehoj HS. Alternatives to antibiotics for maximizing growth performance and feed efficiency in poultry: a review. Anim Health Res Rev. 2017;18(1):26-45.

5. Jung WK, Koo HC, Kim KW, Shin S, Kim SH, Park YH. Antibacterial activity and mechanism of action of the silver ion in Staphylococcus aureus and Escherichia coli. Appl Environ Microbiol. 2008;74(7):2171-8.

6. Yadav JP, Das SC, Dhaka P, Vijay D, Kumar M, Mukhopadhyay AK, Chowdhury G, Chauhan P, Singh R, Dhama K, et al. Molecular characterization and antimicrobial resistance profile of Clostridium perfringens type a isolates from humans, animals, fish and their environment. Anaerobe. 2017;47:120-4.

7. O'Driscoll NH, Cushnie TPT, Matthews KH, Lamb AJ. Colistin causes profound morphological alteration but minimal cytoplasmic membrane perforation in populations of Escherichia coli and Pseudomonas aeruginosa. Arch Microbiol. 2018;200(5):793-802.

8. Dholvitayakhun A, Trachoo N, N-a N, Cushnie TPT. Using scanning and transmission electron microscopy to investigate the antibacterial 
mechanism of action of the medicinal plant Annona squamosa Linn. J Herbal Med. 2017;7:31-6.

9. de Souza W, Attias M. New advances in scanning microscopy and its application to study parasitic protozoa. Exp Parasitol. 2018;190:10-33.

10. Fultz B, Howe JM. Transmission electron microscopy and diffractometry of materials: Springer Science \& Business Media; 2012.

11. Kasetti RB, Rajasekhar MD, Kondeti VK, Fatima SS, Kumar EGT, Swapna S, Ramesh B, Rao CA. Antihyperglycemic and antihyperlipidemic activities of methanol: water (4: 1) fraction isolated from aqueous extract of Syzygium alternifolium seeds in streptozotocin induced diabetic rats. Food Chem Toxicol. 2010;48(4):1078-84.

12. de Souza AM, de Oliveira CF, de Oliveira VB, Betim FCM, Miguel OG, Miguel MD. Traditional uses, Phytochemistry, and antimicrobial activities of Eugenia species-a review. Planta Med. 2018;84(17):1232-48.

13. Gaylard A, Kerley Gl. Diet of tree hyraxes Dendrohyrax arboreus (Hyracoidea: Procaviidae) in the eastern cape, South Africa. J Mammal. 1997;78(1):213-21.

14. Semenya SS, Maroyi A. Ethnobotanical survey of plants used by Bapedi traditional healers to treat tuberculosis and its opportunistic infections in the Limpopo Province, South Africa. S Afr J Bot. 2019; 122:401-21

15. Famuyide IM, Aro AO, Fasina FO, Eloff JN, McGaw LJ. Antibacterial activity and mode of action of acetone crude leaf extracts of underinvestigated Syzygium and Eugenia (Myrtaceae) species on multidrug resistant porcine diarrhoeagenic Escherichia coli. BMC Vet Res. 2019; 15(1):162.

16. Bouhdid S, Abrini J, Zhiri A, Espuny M, Manresa A. Investigation of functional and morphological changes in Pseudomonas aeruginosa and Staphylococcus aureus cells induced by Origanum compactum essential oil. J Appl Microbiol. 2009;106(5):1558-68.

17. Toné $S$, Sugimoto $K$, Tanda K, Suda T, Uehira K, Kanouchi H, Samejima $K$, Minatogawa Y, Earnshaw WC. Three distinct stages of apoptotic nuclear condensation revealed by time-lapse imaging, biochemical and electron microscopy analysis of cell-free apoptosis. Exp Cell Res. 2007;313(16):363544.

18. Voget M, Lorenz D, Lieber-Tenorio E, Hauck R, Meyer M, Cieslicki M. Is transmission electron microscopy (TEM) a promising approach for qualitative and quantitative investigations of polymyxin B and miconazole interactions with cellular and subcellular structures of Staphylococcus pseudintermedius, Escherichia coli, Pseudomonas aeruginosa and Malassezia pachydermatis? Vet Microbiol. 2015;181(3):261-70.

19. Wasfi R, Elkhatib WF, Khairalla AS. Effects of selected Egyptian honeys on the cellular ultrastructure and the gene expression profile of Escherichia coli. PLoS One. 2016;11(3):e0150984.

20. Wu VC-H, Qiu X, Bushway A, Harper L. Antibacterial effects of American cranberry (Vaccinium macrocarpon) concentrate on foodborne pathogens. LWT Food Sci Technol. 2008:41(10):1834-41.

21. El-Maati MFA, Mahgoub SA, Labib SM, Al-Gaby AMA, Ramadan MF. Phenolic extracts of clove (Syzygium aromaticum) with novel antioxidant and antibacterial activities. Eur J Integr Med. 2016;8(4):494-504.

22. Shen $S$, Zhang $T$, Yuan $Y$, Lin $S, X u J, Y e ~ H$. Effects of cinnamaldehyde on Escherichia coli and Staphylococcus aureus membrane. Food Microbiol. 2015; 47:196-202.

23. Saito ST, DdS T, Macedo AJ, Pungartnik C, Gosmann G, JdD S, Guecheva TN, JAP H, Brendel M. Bioguided fractionation shows Cassia alata extract to inhibit Staphylococcus epidermidis and Pseudomonas aeruginosa growth and biofilm formation. Evid Based Complement Alternat Med. 2012:2012:867103.

24. Yang X, Huang E, Yousef AE. Brevibacillin, a cationic lipopeptide that binds to lipoteichoic acid and subsequently disrupts cytoplasmic membrane of Staphylococcus aureus. Microbiol Res. 2017;195:18-23.

25. Shai LJ, McGaw LJ, Aderogba MA, Mdee LK, Eloff JN. Four pentacyclic triterpenoids with antifungal and antibacterial activity from Curtisia dentata (Burm.F) C.a. Sm. Leaves. J Ethnopharmacol. 2008;119(2):23844.

26. Chung PY, Navaratnam P, Chung LY. Synergistic antimicrobial activity between pentacyclic triterpenoids and antibiotics against Staphylococcus aureus strains. Ann Clin Microbiol Antimicrob. 2011; 10(1):25.

27. Kotzé M, Eloff JN, Houghton PJ. Extraction of antibacterial compounds from Combretum microphyllum (Combretaceae). S Afr J Bot. 2002;68(1):62-7.
28. Eloff JN. Antibacterial activity of Marula (Sclerocarya birrea (a. rich.) Hochst. Subsp. caffra (Sond.) Kokwaro) (Anacardiaceae) bark and leaves. J Ethnopharmacol. 2001;76(3):305-8.

29. Van der Merwe CF, Peacock J. In: 1999: Enhancing conductivity of biological material for SEM. Microscopy Society of southern Africa: 38th Conference Proceedings, Bloemfontein, South Africa; 1999. p. 24.

30. Yadav AK, Saraswat S, Sirohi P, Rani M, Srivastava S, Singh MP, Singh NK. Antimicrobial action of methanolic seed extracts of Syzygium cumini Linn. on Bacillus subtilis. AMB Express. 2017;7(1):196.

\section{Publisher's Note}

Springer Nature remains neutral with regard to jurisdictional claims in published maps and institutional affiliations.
Ready to submit your research? Choose BMC and benefit from:

- fast, convenient online submission

- thorough peer review by experienced researchers in your field

- rapid publication on acceptance

- support for research data, including large and complex data types

- gold Open Access which fosters wider collaboration and increased citations

- maximum visibility for your research: over $100 \mathrm{M}$ website views per year

At BMC, research is always in progress.

Learn more biomedcentral.com/submissions 